decreases, whereas an increasing part of the ingested starch $(6 \mathrm{p}$. Ioo after I6 days and $2 \mathrm{I}$ p. Ioo after 26 days of $\mathrm{N}$-free diet) is excreted in the faeces.

$2^{\circ}$ Immature (50 p. roo DM) maize (corn and cobs) may be dehydrated or ensiled. Under this last form, the digestibility of the components of the dry matter is higher and, correlatively, the following facts are observed :

a) decrease of the intestinal transit rate,

b) important amylolytic activity in the stomach but reduced in the small intestine, in comparison with that observed on the dehydrated maize diet,

c) an always higher rate of amylolysis : one hour after the silage meal, 26.4 (expressed as p. Ioo of the ingested starch) are recovered in the stomach, 0.6 in the small intestine and 0.1 in the large intestine, vs $65 \cdot 0-3.5-9.5$ respectively for the dehydrated product.

\title{
UTILISATION DIGESTIVE DES ACIDES GRAS
}

\author{
J. FLANZY \\ Station de Recherches de Nutrition, \\ Centre national de Recherches zootechniques, I. N. R. A., \\ 78 - Jouy-en-Josas
}

La digestibilité des acides gras ingérés sous forme de triglycérides mixtes a été étudiée chez le Porc. Les CUD moyens apparents obtenus sont les suivants : acide laurique, 90 p. Ioo ; acide myristique, 67 p. roo ; acide palmitique, 46 p. roo; acide stéarique, $4^{\circ}$ p. Ioo; acide oléique, 90 p. 100 ; acide linoléique, 95 p. Ioo.

La faible digestibilité de certaines graisses est liée à une augmentation de la proportion de composés insolubles retrouvée dans les fèces. Ces composés insolubles, vraisemblablement des sels de $\mathrm{Ca}^{++}$, se formeraient au cours de la digestion, dans la lumière intestinale, surtout à partir des acides saturés, palmitique et stéarique.

L'influence de la structure glycéridique a été étudiée : en effet, quand l'acide palmitique est en position $\beta$ dans la molécule de triglycéride (cas du saindoux), il est absorbé sous forme de $\beta$-monoglycéride. Son CUD apparent est alors de $86 \mathrm{p}$. гоo.

Chez le Rat, on a mis en évidence une compétition entre acides gras et acide phosphorique pour la formation des savons de calcium.

Par l'emploi d'animaux axéniques, on a montré l'influence de la flore intestinale sur la digestibilité des acides gras. Le CUD des acides palmitique et stéarique est plus faible dans le cas des animaux holoxéniques que dans celui des animaux axéniques. L'hydrogénation des acides insaturés par la flore intestinale est quantitativement négligeable.

\section{SUMMARY}

\section{DIGESTIVE UTILIZATION OF FATTY ACIDS}

Digestibility of fatty acids ingested in the form of mixed triglycerides was studied in pigs. The apparent mean digestibilities obtained were as follows : lauric acid 90 p. Ioo, myristic acid 67 p. I0o, palmitic acid 46 p. 100, stearic acid 40 p. Ioo, oleic acid 90 p. Ioo and linoleic acid 95 p. זоo. 
The low digestibility of certain fats was related to an increase in the proportion of insoluble components in faeces. These insoluble components, probably salts of $\mathrm{Ca}^{++}$, would be formed in the lumen of the intestine, particularly from the saturated acids, palmitic and stearic.

The influence of the glyceride structure was studied. In fact, when palmitic acid was situated in the $\beta$ position in the triglyceride molecule (in the case of lard), it was absorbed as $\beta$-monoglyceride. Its apparent digestibility was then $86 \mathrm{p}$. Ioo.

A competition for the development of calcium soaps between fatty acids and phosphoric acid was observed in the Rat.

We have shown the influence of the intestinal microflora upon the digestibility of fatty acids in experiments using axenic animals. The digestive utilization of palmitic and stearic acids was lower in the holoxenic than in the axenic animals. Hydrogenation of the insaturated acids by the intestinal microflora was quantitatively negligible.

\title{
RÉFÉRENCES BIBI,IOGRAPHIQUES
}

Demarne Y., Sacquet E., Flanzy J., Garnier H., Françors A.-C., I97o. Utilisation digestive apparente des acides gras chez le Rat axénique et le Rat holoxénique. Ann. Biol. anim. Bioch. Biophys., $10,369-384$.

Fakambi L., Flanzy J., François A.-C., I969. Compétition in vivo entre acides gras et phosphore pour la formation de composés insolubles de calcium. C. $R$. Acad. Sci., Paris, 269, 2233-2235.

Flanzy J., Rerat A., François A.-C., r968. Étude de l'utilisation digestive des acides gras chez le Porc. Ann. Biol. anim. Bioch. Biophys., 8, 537-548.

\section{DIGESTION DES GRAISSES CHEZ LA TRUIE}

\author{
E. SALMON-LEGAGNEUR et D.-W. FRIEND \\ Station de Recherches sur l'Élevage des Porcs, \\ Centre national de Recherches zootechniques, I. N. R. A., \\ 78 - Jouy-en-Josas
}

Au cours de deux séries d'expériences sur 16 truies en cage de métabolisme, on a étudié la digestibilité des acides gras de différentes graisses (coprah, Maïs, Suif) incorporées à des taux variables $(0,5$, ro p. 100) dans le régime.

Les principales différences observées, qui tiennent soit à la nature de la graisse, soit aux acides gras eux-mêmes, permettent de souligner l'importance de la fraction métabolique endogène des acides gras du contenu intestinal au cours de la digestion (tabl. I).

On remarque en particulier, pour tous les régimes : des quantités non négligeables (o,2 à I $\mathrm{g}$ ) d'acides gras à nombre impair de carbones, la prédominance des acides palmitique et stéarique, surtout dans les régimes riches en acides à longue chaîne (Suif, Maïs), l'absence d'acides insaturés de forme cis (on trouve, par contre, une quantité assez importante d'acide I 8 : I trans, particulièrement avec le régime maïs). 